Bartın Üniversitesi İktisadi ve İdari Bilimler Fakültesi Dergisi, 2020, Cilt 11, Sayı 22

Bartın University Journal of Faculty of Economics and Administrative Sciences, 2020, Volume 11, Issue 22

ISSN: 1309-954X / E-ISSN: 2148-2497

http://iibfdergi.bartin.edu.tr/

http://dergipark.gov.tr/bartiniibf

Araştırma Makalesi, Gönderim Tarihi: 17.06.2020; Kabul Tarihi: 21.10.2020

\title{
Tüketicilerin Spor Ürünlerine İlişkin Çevrimiçi Tüketim Motivasyonlarının ve Elektronik Hizmet Kalitesi Algılarının Yeniden Satın Alma Niyetleri Üzerindeki Etkilerinin İncelenmesi
}

\author{
Doç. Dr. Zehra BOZBAY \\ İstanbul Üniversitesi İşletme Fakültesi, Pazarlama Ana Bilim Dalı \\ zehrat@istanbul.edu.tr, Orcid ID: 0000-0002-2728-8003 \\ Öğr. Gör. Habib Mehmet AKPINAR \\ Haliç Üniversitesi Beden Eğitimi ve Spor Meslek Yüksekokulu, Spor Yöneticiliği Bölümü \\ mehmetakpinar@halic.edu.tr, Orcid ID: 0000-0002-7035-4168
}

\section{$\ddot{O} \mathbf{z}$}

Çalışmanın amacı, tüketicilerin taraftarı oldukları takımın çevrimiçi alışveriş sitelerinden tüketim motivasyonlarının ve alışveriş sitelerine ilişkin elektronik hizmet kalitesi algılarının tüketicilerin satın alma niyetleri üzerindeki etkilerini incelemektir. Bu kapsamda çevrimiçi mağazalara sahip olan ve taraftar sayısı en çok olan dört futbol kulübü taraftarları araştırma kapsamına alınmıştır. Araştırmada anket yöntemi uygulanmış ve 368 tüketiciden veri toplanmıştır. Araştırmada elektronik hizmet kalitesinin ve sporda çevrimiçi tüketim motivasyonunun, çevrimiçi yeniden satın alma niyeti üzerinde etkili olduğu sonucuna ulaşılmıştır. Elektronik hizmet kalitesinin etkinlik ve gizlilik boyutlarının; sporda çevrimiçi tüketim motivasyonun ise ekonomik, kolaylık, çeşitlilik ve sosyalleşme boyutlarının yeniden satın alma niyeti üzerindeki etkilerinin anlamlı olduğu bulunmuştur.

Anahtar Kelimeler: Spor Pazarlaması, Çevrimiçi Alışveriş, Çevrimiçi Tüketim Motivasyonu, Elektronik Hizmet Kalitesi, Yeniden Satın Alma Niyeti

JEL Sınıflandırması: M30, M31, Z20

APA: BOZBAY, Z. ve AKPINAR, H., M. (2020). Tüketicilerin Spor Ürünlerine İlişkin Çevrimiçi Tüketim Motivasyonlarının ve Elektronik Hizmet Kalitesi Algılarının Yeniden Satın Alma Niyetleri Üzerindeki Etkilerinin İncelenmesi. Bartın Üniversitesi İktisadi ve İdari Bilimler Fakültesi Dergisi, 11 (22), 412-430. DOI: 10.47129/bartiniibf.754154 

Perceptions on Repurchase Intention

\title{
Examining the Effects of Consumers' Motivations towards Sports Products and Electronic Service Quality Perceptions on Repurchase Intention
}

\begin{abstract}
The purpose of this study is to examine the effects of consumers' motivation to shop online from and electronic service quality in web of shopping teams' webs on their purchasing intentions. In this study, fans of football club having both online stores and the high number of fans are examined in the scope of the research. Online survey is used in the study and data is collected from 368 consumers. According to the results of the research, the quality of electronic service and motivation of online consumption in sports have effects on the online re-purchase intention. Besides, efficiency and privacy dimensions of electronic service quality and economic, convenience, diversity and socialization dimensions on the online consumption motivation are found to be effective on the online repurchase intention.
\end{abstract}

Keywords: Sport Marketing, Online Shopping, Online Consumption Motivation, eService Quality, Repurchase Intention

JEL Classification: M30, M31, Z20

\section{Giriş}

Toplumlar internetin yaygınlaşması sonucunda giderek küreselleşen bir pazar ortamında büyük değişimlerle dönüşmektedir. İnternet ekonomik yapıyı oluşturan paydaşlar için yeni dijital bir dünya yaratmıştır. Geleneksel pazardan farklı olarak ortaya çıkan dijital dünya tüketicilerin karar alma süreçlerini etkilemiş ve tüketim kararlarında değişikliklere neden olmuştur.

Günümüzde başarılı olmak isteyen işletmeler sosyal ağlar, bloglar ve internet siteleri gibi ortamlarda dijital tüketiciler ile sürekli olarak iletişimde ve etkileşimde bulunarak onları anlamaya çalışmakta ve onlara uygun stratejiler geliştirmektedirler. Yaşanan bu teknolojik gelişmeler sadece geleneksel iletişim yapısını dönüştürmekle kalmamış rekabet kurallarını da yeniden şekillendirmiştir. İnternetin yaygınlaşması ve akıllı telefon kullanımının artmasıyla birlikte pazarlama faaliyetleri dijital ortamlarda, özellikle internet sitelerinde, sosyal medyada ve akıllı telefonlarda gerçekleştirilmektedir (Stephen, 2016). İşletmelerin rakiplerinden daha üstün müşteri değeri yaratmaları ve rekabet üstünlüğü sağlamaları için dijital ortamdaki tüketicilerin davranışlarını anlamaları gerekmektedir.

Meydana gelen tüm bu gelişmeler spor pazarlamasına da yansımıştır. Bu pazarda başarılı olmak için spor sektöründe faaliyet gösteren ve artık bir işletme haline dönüşen kulüpler ve bunları tutundurma amaçlı kullanan markalar spor tüketicilerinin davranışlarını takip etmektedir. Spor içerikleri, spor ürünleri ve hizmetleri internet ortamında en fazla tüketilen değer önerilerinin başında gelmektedir. Spor sektöründe faaliyet gösteren işletmeler de tüketicileri ile iletişime geçmek için sosyal medya 
Tüketicilerin Spor Ürünlerine İlişkin Çevrimiçi Tüketim

Motivasyonlarının ve Elektronik Hizmet Kalitesi Algılarının

platformlarını kullanmaktadır. Facebook bilgi aktarmak için kullanılırken, Youtube üzerinden taraftarları için videolar paylaşılmaktadır. Twitter platformu ise diğer platformlar ile karşılaştırıldığında daha hızlı bir bilgi kaynağı olarak kullanılmaktadır (Witkemper, Lim, \& Waldburger, 2012). Son zamanlarda tüketiciler arasında popüler hale gelen Instagram platformu ise tüketiciler ile etkileşim sağlamak ve onları harekete geçirmek için kullanılmaktadır. Pazarlama faaliyetlerinin giderek geleneksel pazarlardan dijitalleşen pazarlara kaydığı düşünüldüğünde, işletmelerin pazarlama stratejileri içerisinde sosyal medya faaliyetleri önemli bir rol üstlenmektedir.

Elektronik hizmet kalitesi işletmelerin dijital platformlarda başarılı olmasında anahtar belirleyicilerden biri olarak ön plana çıkmaktadır (Carlson \& O'Cass, 2010). Özellikle teknolojik gelişmeler sonucunda ürün ve hizmetlerde meydana gelen standartlaşma sonrası işletmelerin sunmuş oldukları hizmetin niteliği ve kalitesi rekabet avantajı elde etmekte önem taşımaktadır. Son yıllarda, yapılan araştırmalarda dijital tüketicilerin elektronik hizmet kalitesini nasıl algıladıkları ve bu algılarının müşteri memnuniyeti ve davranışsal niyetlerini nasıl etkilediğine ilişkin çalışmalar artmıştır (Udo, Bagchi, \& Kirs, 2010).

Ortaya konan bu değerlendirmeler ışığında çalışmada spor tüketicilerinin internet ortamında yapmış oldukları tüketim motivasyonlarının ve internet ortamında spor kuruluşlarının müşterilerine sunmuş oldukları hizmet kalitesinin boyutlarının belirlenmesi, spor tüketicilerin internet ortamında yapmış oldukları tüketim motivasyonlarının ve internet ortamında e-hizmet kalitesi algılarının yeniden satın alma niyeti üzerindeki etkilerinin incelenmesi amaçlanmıştır.

\section{Literatür Taraması}

\subsection{Spor Ürünlerine İlişkin Çevrimiçi Tüketim}

Hızlı büyüyen bir iletişim ağı olan internet, spor endüstrisi için önemli bir pazarlama aracı ve iletişim mecrası olarak kullanılmaktadır. İnternet kullanıcı sayısının günden güne artması göz önüne alındığında internet spor tüketicileri için birincil bilgi kaynağ 1 olmuş, spor yöneticileri ve pazarlamacılar için önemli pazarlama araçlarından biri haline gelmiştir (Hur, Ko, \& Valacich, 2007). Spor kuruluşları internet siteleri aracılığıyla taraftarları ile iletişim kurarak, ürün ve hizmetlerini sunmaktadırlar (Jae Seo, Christine Green, Jae Ko, Lee, \& Schenewark, 2007).

İnternet siteleri tüketicilere bilgi sağlamada ucuz ve etkili bir yoldur. Ancak internetin bilgi sağlamanın dışında tüketiciler için birçok yararı bulunmaktadır. Spor pazarlaması açısından değerlendirildiğinde spor organizasyon biletlerinin, lisanslı ürünlerin ve hizmetlerin satın alımları için internet kullanımı giderek artmaktadır (Evans \& Smith, 2004). Tüketicilerin spor sitelerine olan ilgisini yönlendiren motivasyonlarını anlamak, spor kuruluşlarının pazarlama faaliyetlerinde kullanacakları bilgileri sağlamaktadır (James \& Ross, 2004). Çevrimiçi spor ürünlerinin tüketiminin artması, spor faaliyetleri ile ilgilenen pazarlamacılar için internetin pazarlama stratejileri içerisinde etkin bir şekilde kullanılması gerekliliğini ortaya koymaktadır. İnternetin sağladığı faydalar göz önüne alındığında işletmelerin spor tüketicilerinin davranışlarını 

Perceptions on Repurchase Intention

anlamaları önemlidir (Hur, Ko, \& Valacich, 2007). İnternet kullanımının yaygınlaşmasıyla beraber çevrimiçi spor tüketicilerinin sayısı arttıkça işletmeler, spor organizasyonlarını, haber sitelerini, bireysel blogları, çevrimiçi mağazaları ve taraftar forumlarını pazarlama araçları olarak kullanmaya başlamışlardır (Hur, Ko, \& Claussen, 2012). Tüketiciler sadece spor ürünleri satın almak için değil, aynı zamanda ilgilendikleri spor dalı ile ilgili bilgi edinmek ve haberleri takip etmek amaciyla spor sitelerini ziyaret etmektedirler. $\mathrm{Bu}$ gelişmeler değerlendirildiğine; internet spor pazarlaması için araç olmaktan çıkarak pazarlama stratejilerinin geliştirilmesinde önemli bir amaç haline gelmiştir (Hur, Ko, \& Valacich, 2007).

Spor kuruluşlarının internet siteleri, spor organizasyonları için bir araç olarak kullanılmakta, spor taraftarları ve organizasyonları arasında bağlantı kurmaktadır. Bu yaklaşımdan hareketle, spor organizasyonları pazarlama hedeflerini gerçekleştirmek ve müşteri memnuniyetini artırmak için internet kullanımlarını arttırmaya çalışmaktadırlar (Hur, Ko, \& Claussen, 2012). Spor etkinlikleri kapsamında çevrimiçi siteleri tüketici deneyimini arttırarak onların daha olumlu bir tutum geliştirmelerine yardımcı olmaktadır. İnternet sitesinde yer alan yönlendirmeler etkinlik biletlerinin satın alınmasını kolaylaştırarak ve tüketicilerin davranışlarında olumlu etkiler yaratarak marka imajına katkı sağlamaktadır (Filo, Funk, \& Hornby, 2009).

İnternetin spor sektörünü etkilemesi, spor pazarlaması ile uğraşan uzmanların ve bilim adamlarının spor ürünleri satın alan tüketicilerin davranışlarını araştırmaya teşvik etmiştir. Pazarlamacılar, tüketicilerin spor ürünlerine ilişkin çevrimiçi tüketim motivasyonlarını inceleyerek onların tüketim kararlarını tahmin etmeye çalışmaktadırlar (Brown, 2003). Spor tüketicilerinin çevrimiçi tüketim davranış motivasyonlarını inceleyen bir çalışmada elde edilen bulgulara göre tüketim motivasyonlarının boyutları hayranlık, kişilerarası iletişim, teknik bilgi, taraftarlık ifadesi, eğlence, ekonomik, başarılı zaman, bilgi, kaçış ve destekleme olarak bulunmuştur (Seo \& Green, 2008).

Literatürde yapılan çalışmalar incelendiğinde Seo ve Green (2008) sporda çevrimiçi tüketimin taraftarlık, kişilerarası iletişim, teknik bilgi, hayranlık ifadesi, eğlence, ekonomik, serbest zaman, bilgi, kaçış ve destekleme olmak üzere on boyuttan oluştuğunu ileri sürmüşlerdir. Tang ve Cooper (2011) internet ortamında ilk kez yayınlanan 2008 Pekin Olimpiyatları'nı konu alan çalışmalarında oyunları internet üzerinden izleyenler ve geleneksel medya kaynakları üzerinden izleyenler arasında anlamlı farklılıklar bulmuşlardır. Bu anlamlı farklılıkların en başında internet üzerinden olimpiyatları takip eden kullanıcıların daha yoğun olarak sporla ve olimpiyatlarla ilgilendiği bulgusuna ulaşılmıştır. Smith ve Smith (2012) tarafından yapılan çalışmada spor tüketicilerinin canlı bir spor etkinliği boyunca Twitter'ı nasıl kullandıkları incelenmiştir. Spor tüketicileri Twitter sosyal medya platformunu birbirleri ile etkileşim amacıyla kullanmaktadırlar. Kang (2015) tarafından yapılan çalışmada profesyonel sporlarda mobil içeriklerin taraftarların sadakatini, takım kimliği ve duyduğu hayranlığ olumlu olarak etkilediği sonucuna ulaşılmıştır. Haugh ve Watkins (2016) taraftarların kullandıkları sosyal medya platformları üzerine bir araştırma yapmışlardır. Bu araştırmanın sonuçlarına göre taraftarların en çok Twitter, Facebook, Instagram ve Snapchat platformlarını kullandıklarını ve kullanım amaçlarını saptamışlardır. 
Tüketicilerin Spor Ürünlerine İlişskin Çevrimiçi Tüketim

Motivasyonlarının ve Elektronik Hizmet Kalitesi Algılarının Yeniden Satın Alma Niyetleri Üzerindeki Etkilerinin İncelenmesi

Taraftarlar Twitter platformunu desteklerini göstermek, kendilerini ifade etmek, kuralları öğrenmek için; Instagram platformunu rahatlamak ve zaman geçirmek için; Facebook platformunu anlaşmaları öğrenmek, bilgi toplamak için kullanırken Snapchat platformunu ise eğlence için kullanmaktadırlar. Ha, Kang ve Kim (2017)'in çalışmasında taraftarların akıllı telefon kullanım motivasyonları belirlenmeye çalışılmıştır. Araştırmada elde edilen bulgulara göre taraftarların kullanım kolaylığına önem verdikleri bulunmuştur. Pazarlama çabalarının başarıya ulaşmasında taraftarlarla etkileşime geçilen internet sitelerinin ve mobil uygulamalarının basit ve kolay anlaşılır olması gerekmektedir. Vale ve Fernandes (2018) tarafından yapılan çalışmada ise taraftarların futbol kulüpleriyle Facebook üzerinden kurmuş olduğu ilişkinin motivasyonları belirlenmeye çalışılmıştır. Araştırmanın sonuçlarına göre bilgi, güçlendirme ve marka aşkı boyutlarının sırasıyla Facebook'taki paylaşımların tüketimi, taraftarların katkısı ve içeriklerin oluşturulması konusunda etkili oldukları belirlenmiştir. Bunun yanı sıra sosyal etkileşim ihtiyacı taraftarların spor kulüpleriyle Facebook üzerinden iletişim kurma motivasyonlarından biri olarak bulunmuştur.

\subsection{Elektronik Hizmet Kalitesi}

Elektronik hizmet kalitesi kavramı sanal pazarlardaki hizmet sunumlarının kalitesinin değerlendirilmesi olarak tanımlanabilir (Santos, 2003). Elektronik hizmet bilgi akışıyla tüketicilere üstün bir deneyim sunmak olarak da tanımlanmıştır (Rust \& Lemon, 2001).

1930'lu yıllarda işletme içerisinde mühendislerin ilgilendiği bir konu olan kalite, sonraki dönemlerde işletmelerin rekabet üstünlüğünü elde etmesinde en önemli faktörlerden biri olarak değerlendirilmiştir (Boshoff, 2007). İnternet kullanımının yaygınlaşmasıyla birlikte büyüyen elektronik ticaret, işletmelerin tüketicileri ile elektronik ticareti kullanarak rekabet üstünlüğ̈̈ yaratmasını sağlayacak faaliyetleri gerçekleştirmelerini sağlamıştır. Elektronik ticaret sitelerinin başarıya ulaşmalarında; düşük fiyat, internet sitesinin özellikleri ve elektronik hizmet kalitesi önemli rol oynamaktadır (Zeithaml, 2002). İnternet üzerinden faaliyet gösteren bir işletmenin başarılı olabilmesi tedarikçisinden müşteri hizmetlerine kadar olan süreçte ne kadar bütünleşik bir sistem kurulduğu ile yakından ilgilidir (Cox \& Dale, 2001). Elektronik ticaretle uğraşan işletmelerin başarılı olması ve müşteri tatmini sağlaması için e-hizmet kalitesinin yüksek olması gerekmektedir (Chang, Wang, \& Yang, 2009). Elektronik hizmet kalitesi satın alma öncesi ve satış sonrası için değerlendirilmektedir. Satın alma öncesi aşamada kullanım kolaylığı, ürün, sipariş takibi ve kişisel verilerin korunması gibi özellikler ön plana çıkmaktadır. Satış sonrası aşama ise teslimatı, müşteri hizmetlerini ve iade prosedürlerini kapsamaktadır (Ladhari, 2010).

Literatür incelendiğinde, tüketicilerin hizmet kalitesi algılarını ve hizmet kalitesini etkileyen boyutlara yönelik çalışmalar yer almaktadır. Grönroos (2007) hizmeti, algılanan kalite ile tüketici beklentilerinin tüketici tarafından karşılaştırılarak değerlendirilme süreci olarak tanımlamıştır. $\mathrm{Bu}$ değerlendirme hizmetin algılanan kalitesi olarak açıklanmıştır (Grönroos, 1984). Hizmet kalitesi, verilen hizmet 

Perceptions on Repurchase Intention

seviyesinin müşteri beklentilerine ne kadar uyum sağladığının bir ölçüsüdür (Parasuraman, Zeithaml, \& Leonard, 1985).

Geleneksel hizmet kalitesi fiziksel unsurlar, güvenilirlik, heveslilik, güvence ve empati olmak üzere beş boyuttan oluşmaktadır (Parasuraman, Zeithaml, \& Berry, 1988). Elektronik hizmet kalitesinin boyutlarına ilişkin literatürde yapılan birçok çalışma söz konusudur. Yo ve Donthu (2001) tarafindan yapılan çalışmaya göre elektronik hizmet kalitesi kullanım kolaylığı, estetik dizayn, işlem hızlılığı ve güvenlik olmak üzere dört boyuttan oluşmaktadır. Zeithaml ve diğerleri (2000) tarafindan gerçekleştirilen çalışmada ise elektronik hizmet kalitesi erişim, erişim kolaylığı, esneklik, güvenilirlik, kişiselleştirme, güvenlik-gizlilik, cevap verebilirlik, güven, estetik ve fiyat bilgisi olmak üzere 11 boyuttan oluşmaktadır. Literatürde yer alan diğer bir çalışamada ise elektronik hizmet kalitesi internet sitesi tasarımı, güvenilirlik, duyarlılık, güven ve kişiselleştirme alt boyutlarından oluşmaktadır (Lee \& Lin, 2005). Parasuraman ve diğerleri (2005) tarafından yapılan çalışmada e-hizmet kalitesinin etkinlik, gerçekleştirme, sistem ulaşılabilirliği ve gizlilik olmak üzere dört boyuttan oluştuğu öne sürülmüştür. Etkinlik boyutu erişim kolaylığı, site hızı ve kullanılabilirliği; gerçekleştirme sitenin sipariş teslimi ve ürün mevcudiyetine ilişkin bilgi vermesi; sistem ulaşılabilirliği sitenin teknik olarak sorunsuz bir şekilde çalışması; gizlilik ise sitenin güvenilirliğinin derecesi ve müşteri bilgilerini korunmasıdır (Parasuraman, Zeithaml, \& Malhotra, 2005).

Biscaia ve diğerleri (2013) tarafindan hizmet kalitesinin bilet fiyatlandırmasına ilişkin memnuniyet ve niyet üzerine yapılan çalışmada hizmet kalitesinin hem memnuniyeti hem de niyet üzerinde etkili olduğu sonucuna ulaşılmıştır. Özellikle futbolcunun göstermiş olduğu performans ve stadın atmosferine ilişkin tatmini ve niyeti etkileyen boyut olarak ön plana çıkmıştır. Chiu ve Won (2016) sporla ilgili internet sitesinin sahip olduğu kalitenin sporla ilgili medya tüketiminde etkili olduğunu fakat yeniden ziyaret etme niyeti üzerinde etkili olmadığ 1 sonucuna ulaşmışlardır. Foroughi ve diğerleri (2016) tarafından yapılan çalışmada ise temel ürün kalitesi (takım özellikleri ve oyuncu performansı), taraftarların duygu ve davranış niyetleri arasındaki ilişkiler incelenmiştir. Araştırmanın sonuçlarına göre temel ürün kalitesinin kaygı, mutluluk ve heyecan duyguları ile ilişkili olduğu sonucuna ulaşılmıştır. Oman, Pepur ve Arneric (2016) tarafindan yapılan çalışmada ise hizmet kalitesi yeniden satın alma niyeti ve takım özdeşlemesi üzerinde doğrudan etkiye sahipken, ağızdan ağıza iletişim ve yeniden satın alma niyeti arasında aracı etkiye sahiptir. Lee (2017) spor salonlarındaki hizmet kalitesinin tüketici sadakati üzerine etkisini araştırmıştır. Hizmet kalitesi müşteri sadakatini olumlu yönde etkilemektedir. Bunun yanında spor merkezlerinin sahip olduğu hizmet kalitesi tüketicilerin egzersiz yapmalarına bağlı kalmalarını olumlu yönde etkilediği sonucuna ulaşılmıştır.

\section{3. Çevrimiçi Yeniden Satın Alma Niyeti}

İnternet üzerinden yapılan işlemlere yönelik güvenilirliğin artması, internet sitelerinin işlevlerindeki ve tasarımlarındaki gelişmeler, tüketicilerin e-ticaret konusundaki algılarını daha olumlu hale getirerek çevrimiçi alışveriş ortamını olgunlaşan bir ticari kanala dönüştürmüştür. Bu gelişmeler ele alındığında çevrimiçi 
Tüketicilerin Spor Ürünlerine İlişkin Çevrimiçi Tüketim Motivasyonlarının ve Elektronik Hizmet Kalitesi Algılarının Yeniden Satın Alma Niyetleri Üzerindeki Etkilerinin İncelenmesi

tüketicilerin satın alma niyetlerinin araştırılması işletmeler için oldukça önem kazanmıştır (Wen, Prybutok, \& Xu, 2011). Çevrimiçi satın alma niyeti, ilgili alışveriş sitelerinin yeniden ziyaret edilmesinden ziyade tekrarlanan alışveriş etkinlikleriyle alışveriş yapmaya devam etme konusunda müşteri sürekliliği olarak ifade edilebilir (Chou \& Hsu, 2016).

Tüketicilerin satın alma davranışlarını anlamak, işletmeler için müşteri elde etmede ve korumada büyük bir öneme sahiptir (Eunju, Kim, \& Zhang, 2008). Satın alma niyeti, tüketicinin gelecekte satın alma olasılığı olarak tanımlanmıştır (Kim \& Ko, 2010).

Çevrimiçi satın alma niyeti, tüketicinin internet üzerinden belirli bir satın alma davranışını sürdürme niyetini belirtmektedir (Salisbury, Pearson, Pearson, \& Miller, 2001). Çevrimiçi satın alma niyeti, bir tüketicinin çevrimiçi işlemde bulunmaya istekliği olduğu ve planladığı durumdur. Çevrimiçi işlemler, bilgi alma, bilgi aktarma ve ürün satın alma işlemlerinin yapıldığ

Zhou, Lu ve Wang (2009) tarafindan yapılan çalışmada internet sitesi tasarımı ile hizmet kalitesinin yeniden satın alım niyeti üzerindeki etkileri araştırılmıştır. İnternet sitesi tasarımı ve hizmet kalitesi yeniden satın alma niyeti üzerinde etkilidir ancak hizmet kalitesi tüketicilerin memnuniyeti üzerinde internet sitesi tasarımından daha güçlü etkilere sahiptir. Thedorakis ve diğerleri (2009) tarafından yapılan çalışmada taraftarların takım kimliğinin hizmet kalitesi ve yeniden satın alma ilişkisi arasındaki aracı etkisi incelenmiştir. Çalışmada takım kimliğinin hizmet kalitesi ve yeniden satın alma niyeti arasında aracılık etkisine sahip olduğu bulunmuştur. Srivastava ve Sharma (2013) tarafından yapılan çalışmada yüksek hizmet kalitesinin ve güvenilir bir kurumsal imajın yüksek müşteri memnuniyeti sağladığı ve bunun sonucunda da yeniden satın almanın gerçekleştiği sonucuna ulaşılmıştır. Chiu ve Won (2016) tarafından yapılan çalışmada spor ürünleri satın alan tüketicilerin marka bağlılıklarının yeniden satına alma niyetlerini olumlu olarak etkilediği sonucuna ulaşılmıştır.

$\mathrm{Bu}$ çalışmada çevrimiçi tüketin motivasyonunun ve elektronik hizmet kalitesinin yeniden satına alma niyeti üzerinde etkileri incelenmiştir.

\section{Yöntem}

\subsection{Araştırmanın Amacı, Kapsamı ve Kısıtları}

Spor pazarlaması çerçevesinde spor kulüplerinin tüketicileri olan taraftarların çevrimiçi tüketim motivasyonlarının belirlenmesi ve spor kulüplerinin sahip oldukları çevrimiçi mağazalarının hizmet kalitesinin yeniden satın alma niyetine olan etkisinin ortaya konulması araştırmanın amacıdır. Araştırma kapsamında taraftarların çevrimiçi mağazalarda alışveriş yaparken sahip oldukları motivasyonları belirlemek aynı zamanda alışveriş sitelerinin hizmet kalitesinin belirlenmesi yolu ile çevrimiçi alışveriş̧ stratejilerinde spor kulüplerine yol göstermek amaçlanmıştır. Bu amaçlar doğrultusunda taraftarların çevrimiçi tüketim motivasyonlarının, elektronik hizmet kalitesinin, yeniden 

Perceptions on Repurchase Intention

satın alma niyetinin ve sosyo-demografik özelliklerinin belirlenmesine yönelik sorulardan oluşan bir anket formu hazırlanmıştır.

Literatürde taraftarların çevrimiçi motivasyonları ve spor kulüplerinin çevrimiçi mağazalarının elektronik hizmet kalitesine ilişkin algılarını inceleyen çalışmaların sınırlı olması nedeniyle araştırmanın sonuçlarının önemli olacağı düşünülmektedir.

Araştırma kapsamında çevrimiçi mağazalara sahip olan ve Türkiye'nin en büyük taraftar gruplarına sahip olan Beşiktaş, Fenerbahçe, Galatasaray ve Trabzonspor takımları seçilmiştir. Araştırma çevrimiçi mağazaları olan dört futbol kulübü taraftarı ile sınırlandırılmıştır.

Araştırmanın anakütlesini 18 yaş ve üzeri Beşiktaş, Fenerbahçe, Galatasaray ve Trabzonspor spor kulübü taraftarlarından bu takımlara ait çevrimiçi mağazalardan en az bir kere alışveriş yapmış tüketiciler oluşturmaktadır. Çevrimiçi alışveriş yapan taraftarların sayılarının tam olarak belirlenememesinden dolayı örnekleme sürecinde tesadüfi olmayan örnekleme yöntemlerinden kolayda örnekleme seçimi yapılmıştır. Araştırmada 384 kişiye ulaşılmış olup belirli sebeplerden dolayı 15 anket değerlendirmeye alınmamış ve toplam 368 anket üzerinden analizler gerçekleştirilmiştir.

\subsection{Araştırmanın Modeli ve Hipotezleri}

Sporda çevrimiçi tüketim motivasyonu, elektronik hizmet kalitesi, yeniden satın alma niyeti araştırmanın temel değişkenlerini oluşturmaktadır. Araştırmanın modeli aşağıda yer almaktadır.

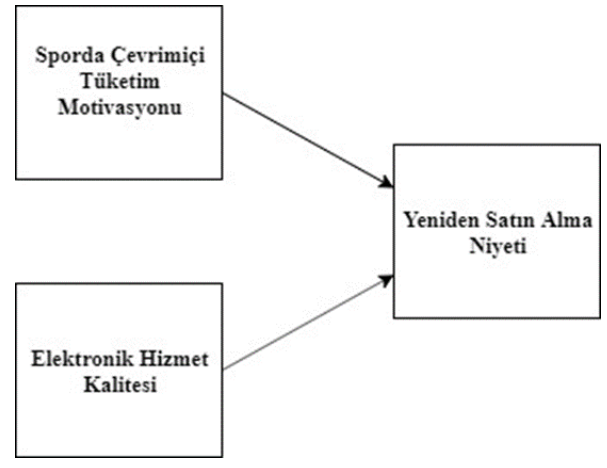

Şekil 1: Araştırmanın Modeli

Araştırmanın modeli kapsamında, spor pazarlamasında çevrimiçi tüketim motivasyonunu ölçmek üzere, Seo ve Green'in (2008) çalışmalarından, elektronik hizmet kalitesini ölçmek üzere literatürde birçok çalışmada kullanılmış olan 
Tüketicilerin Spor Ürünlerine İlişkin Çevrimiçi Tüketim Motivasyonlarının ve Elektronik Hizmet Kalitesi Algılarının

Parasuraman, Zeithaml ve Malhotra'nın (2005) çalışmalarından, çevrimiçi yeniden satın alma niyeti ölçeği için ise You ve Donth'nun (2001) çalışmalarından yararlanılmıştır.

Araştırmada sporda çevrimiçi tüketim motivasyonuna ilişkin ölçekte 30, elektronik hizmet kalitesine ilişkin ölçekte 22, çevrimiçi satın alma niyeti ilişkin ölçekte altı ifade yer almaktadir.

Araştırmanın amacı doğrultusunda geliştirilen hipotezler şu şekildedir:

$\mathrm{H}_{1}$ : Çevrimiçi tüketim motivasyonu çevrimiçi yeniden satın alma niyeti üzerinde etkilidir. etkilidir.

$\mathrm{H}_{2}$ : Elektronik hizmet kalitesi çevrimiçi yeniden satın alma niyeti üzerinde

\subsection{Araştırmaya Katılanların Sosyo Demografik Özellikleri}

Tablo 1'de araştırmaya dahil olan 368 katılımcının sosyo-demografik özelliklerine ilişkin bilgiler yer almaktadır.

\section{Tablo 1: Katılımcıların Sosyo-Demografik Özellikleri}

\begin{tabular}{|l|l|l|l|l|l|}
\hline Yaş & Frekans & Yüzde (\%) & Cinsiyet & Frekans & Yüzde (\%) \\
\hline $18-25$ & 156 & 42.4 & Kadın & 239 & 64,9 \\
\hline $26-33$ & 86 & 23.4 & Erkek & 129 & 35,1 \\
\hline $34-41$ & 76 & 20.7 & Toplam & 368 & 100,0 \\
\hline $42-49$ & 40 & 10.9 & Medeni Durum & Frekans & Yüzde (\%) \\
\hline $50-57$ & 10 & 2.7 & Bekar & 252 & 68.5 \\
\hline Toplam & 368 & 100,0 & Evli & 116 & 31.5 \\
\hline Gelir & Frekans & Yüzde (\%) & Toplam & 368 & 100,0 \\
\hline $1500 T L$ ve altı & 112 & 30,4 & Eğitim & Frekans & Yüzde (\%) \\
\hline $1501-3000 T L$ & 102 & 27.7 & İlköğretim & 17 & 4,6 \\
\hline $3001-4500 T L$ & 72 & 19.6 & Lise & 123 & 33,4 \\
\hline $4501-6000 T L$ & 58 & 15.8 & Ön Lisans & 46 & 12,5 \\
\hline $6001 T L$ ve üstü & 23 & 6.5 & Lisans & 142 & 40,0 \\
\hline Toplam & 368 & 100,0 & Yüksek Lisans / Doktora & 40 & 10,9 \\
\hline Meşguliyet Durumu & Frekans & Yüzde (\%) & Toplam & 368 & 100,0 \\
\hline Öğrenci & 130 & 35.3 & & & \\
\hline Özel Sektör Çalışanı & 88 & 23.9 & & & \\
\hline Kamu Sektörü Memur & 44 & 12.0 & & & \\
\hline Serbest Meslek Sahibi & 43 & 11.7 & & & \\
\hline Esnaf & 41 & 11.1 & & & \\
\hline İşçi & 12 & 3.3 & & & \\
\hline
\end{tabular}




\begin{tabular}{|l|l|l|l|l|l|}
\hline Çalı̧mıyorum & 10 & 2.7 & & & \\
\hline Toplam & 368 & 100,0 & & & \\
\hline
\end{tabular}

Tablo 1 incelendiğinde araştırmaya katılanların çoğunluğunun 18-24 yaş aralığında, orta ve alt gelir düzeyine sahip, öğrenci ve özel sektör çalışanı olan erkeklerden oluştuğu görülmektedir. Ayrıca, araştırmaya katılanların \%91'ini İstanbul'un üç büyük takımının futbol taraftarları oluşturmaktadır. Katılımcılar internet sitelerinden en fazla giyim ürünleri satın alırken, bu kategoriyi forma ve çocuk-bebek ürünlerinin takip ettiği görülmektedir.

Araştırmada öncelikle ölçeklerin geçerlilik ve güvenilirlikleri test edilmiştir. Araştırmada kullanılan ölçeklerin geçerliliklerinin test edilebilmesi için keşfedici faktör analizinden ve araştırmada kullanılan ölçeklerin güvenilirliklerinin belirlenebilmesi için Cronbach's alfa katsayısından yararlanılmıştır.

Tablo 2'de taraftarların sporda çevrimiçi tüketim motivasyonları, elektronik hizmet kalitesi algılarını ve yeniden satın alma niyetlerini ölçen ifadelerin faktör yükleri ve açıklanan varyans yüzdeleri yer almaktadır.

Tablo 2: Elektronik Hizmet Kalitesi, Sporda Çevrimiçi Tüketim Motivasyonu ve Çevrimiçi Yeniden Satın Alma Niyetine İlişkin Keşfedici Faktör Analizi Sonucu

\begin{tabular}{|c|c|}
\hline Faktör Ífadeleri & $\begin{array}{l}\text { Faktör } \\
\text { Yükleri }\end{array}$ \\
\hline \multicolumn{2}{|l|}{ Sporda Çevrimiçi Tüketim Motivasyonu } \\
\hline \multicolumn{2}{|l|}{ Ekonomik } \\
\hline $\begin{array}{l}\text { İnternet üzerinden sporla ilgili ürün satın almanın mükemmel bir pazarlık olduğunu } \\
\text { düşünürüm. }\end{array}$ & ,790 \\
\hline İnternet üzerinden sporla ilgili ürünleri satın almak kesinlikle karşılığına değer. & ,821 \\
\hline İnternetteki sporla ilgili ürünlerin veya hizmetlerin fiyatları çok iyidir. & ,784 \\
\hline \multicolumn{2}{|l|}{ Güvenlik ve Gizlilik } \\
\hline Bilgilerimi internet üzerinden göndermekten kendimi rahatsız hissederim & 653 \\
\hline $\begin{array}{l}\text { Kişisel ve finansal bilgilerimin rızam olmadan başkalarıyla paylaşılabileceğinden endişe } \\
\text { duyarım. }\end{array}$ & ,715 \\
\hline İnternette kredi kartı numaramı vermek beni rahatsız eder. & ,748 \\
\hline İnternetteki kişisel bilgilerimin güvenliği konusunda endișe duyarım. & ,764 \\
\hline \multicolumn{2}{|l|}{ Teslimat } \\
\hline İnternet üzerinde satın alınan ürünlerde teslimat sorunları vardır. & ,732 \\
\hline İnternet üzerinden satın alınan ürünlerin teslimat saatini ve tarihi bilinmez. & 672 \\
\hline İnternet üzerinden satın aldığım ürünün nerede olduğunu takip edemem. & 572 \\
\hline \multicolumn{2}{|l|}{ Ürün Kalitesi } \\
\hline $\begin{array}{l}\text { İnternet üzerinden ürün satın almadan önce ürünleri dokunmama ve hissetmememden hoşnut } \\
\text { olmam. }\end{array}$ & ,544 \\
\hline İnternet üzerinden satın alınan ürünlerde, ürün kalitesini değerlendirmek zordur. & ,668 \\
\hline İnternet üzerinden satın aldığım ürünün çalışıp çalışmadığını konusunda endişelenirim. & ,740 \\
\hline İnternet üzerinden satın aldığım ürünün olup sahte olup olmadığı konusunda endişeliyim. & ,681 \\
\hline \multicolumn{2}{|l|}{ Müşteri Hizmetleri } \\
\hline Çevrimiçi perakendecilerin satış sonrası hizmetlerinden endişe duyarım. & ,769 \\
\hline Çevrimiçi perakendecilerden yanıt alınması çok zaman alır. & ,704 \\
\hline
\end{tabular}


Tüketicilerin Spor Ürünlerine İlişkin Çevrimiçi Tüketim

Motivasyonlarının ve Elektronik Hizmet Kalitesi Algılarının

\begin{tabular}{|c|c|}
\hline Bu çevrimiçi alışveriş sitesini boş zamanımı değerlendirmek için kullanırım. & ,787 \\
\hline $\begin{array}{l}\text { İnternet üzerinden satın aldığım ürünlerde bir sorun ortaya çıktığında kiminle irtibat kurmam } \\
\text { gerektiğini bilemem. }\end{array}$ & ,677 \\
\hline \multicolumn{2}{|l|}{ Kolaylık } \\
\hline İnternet üzerinden alışveriş yaptığım spor ilgili ürünlerin esnekliğini beğenirim. & ,622 \\
\hline $\begin{array}{l}\text { İnternet, sporla alakalı ürünler için alışveriş yaparken alımımı kendi hızımda yapmayı } \\
\text { kolaylaştırır. }\end{array}$ &, 824 \\
\hline İnterneti kullanmak, sporla ilgili ürünler için alışveriş yapmayı kolaylaştırır. & ,807 \\
\hline \multicolumn{2}{|l|}{ Bilgi } \\
\hline İnterneti kullanarak spor endüstrisinde olup biten son gelişmeleri öğrenirim. & ,718 \\
\hline İnternetten spor ile ilgili edinilen bilgiler faydalıdır. &, 635 \\
\hline $\begin{array}{l}\text { Takım performansı, oyuncu profilleri ve maç programları gibi çeşitli spor bilgilerini } \\
\text { internetten edinebilirim. }\end{array}$ & ,756 \\
\hline \multicolumn{2}{|l|}{ Çeşitlilik } \\
\hline Spor ile ilgili internet sitelerini kullanmak beni heyecanlandırır. &, 808 \\
\hline Sporla ilgili internet sitelerini kullanmak, duygularımı ve hislerim uyandırır. & ,661 \\
\hline $\begin{array}{l}\text { Sporla ilgili internet sitelerini kullanmak, benim günlük rutinden kaçmam için bir çıkış } \\
\text { noktası sağlar. }\end{array}$ & ,586 \\
\hline \multicolumn{2}{|l|}{ Sosyalleşme } \\
\hline $\begin{array}{l}\text { İnternet üzerinden spor takımları ve oyuncular hakkında fikirlerimi paylaşmaktan } \\
\text { hoşlanırım. }\end{array}$ &, 650 \\
\hline İnternet üzerinden spor ile ilgili konuları tartışmaktan keyif alırım. & ,688 \\
\hline KMO & ,880 \\
\hline Açıklanan Toplam Varyans & 68,652 \\
\hline Cronbach's Alpha & ,936 \\
\hline \multicolumn{2}{|l|}{ Elektronik Hizmet Kalitesi } \\
\hline \multicolumn{2}{|l|}{ Etkinlik } \\
\hline Bu çevrimiçi alışveriş sitesini ihtiyacım olanı bulmamı kolaylaştırır. & ,841 \\
\hline Bu çevrimiçi alışveriş sitesine herhangi bir yerden kolayca ulaşabilir. &, 878 \\
\hline Bu çevrimiçi alışveriş sitesi işlemleri hızlı bir şekilde tamamlar. & ,891 \\
\hline Bu çevrimiçi alışveriş sitesindeki bilgiler iyi düzenlenmiştir. & ,681 \\
\hline Bu çevrimiçi alışveriş sitesi sayfaları hızlı bir şekilde yükler &, 827 \\
\hline $\mathrm{Bu}$ çevrimiçi alışveriş sitesinin kullanımı kolaydır. & ,904 \\
\hline Bu çevrimiçi alışveriş sitesine kolayca ulaşırım. &, 898 \\
\hline Bu çevrimiçi alışveriş siteyi iyi bir şekilde düzenlenmiştir. &, 723 \\
\hline \multicolumn{2}{|l|}{ Sistem Ulaşılabilirliği } \\
\hline Bu çevrimiçi alışveriş sitesi doğru bir şekilde çalışır. & ,900 \\
\hline Bu çevrimiçi alışveriş sitesi çökmez. & ,714 \\
\hline Sipariş bilgilerimi girdikten sonra bu çevrimiçi alışveriş sitesi donmaz. &, 805 \\
\hline \multicolumn{2}{|l|}{ Gerçekleştirme } \\
\hline Bu çevrimiçi alışveriş sitesi siparişlerin teslimatını söz verdiği şekilde yapar. & ,857 \\
\hline Bu çevrimiçi alışveriş sitesi siparişleri uygun zaman içerisinde teslimata hazır hale getirir. &, 873 \\
\hline Bu çevrimiçi alışveriş sitesi siparişlerimi hızlı bir şekilde gönderir. & ,848 \\
\hline $\mathrm{Bu}$ çevrimiçi alışveriş sitesini satışa sunduğu ürünleri stokta bulundurur. & ,908 \\
\hline $\mathrm{Bu}$ çevrimiçi alışveriş sitesini sipariş ettiğim ürünleri gönderir. & ,678 \\
\hline Bu çevrimiçi alışveriş sitesini satışa sunduğu ürünleri stokta bulundurur. & ,726 \\
\hline Bu çevrimiçi alışveriş sitesinin teklifine güvenilir. & ,908 \\
\hline Bu çevrimiçi alışveriş sitesi teslimatı verdiği sözler doğrultusunda gerçekleştirir. &, 834 \\
\hline Gizlilik & \\
\hline
\end{tabular}


Examining the Effects of Consumers' Motivations towards Sports Products and Electronic Service Quality Perceptions on Repurchase Intention

\begin{tabular}{|c|c|}
\hline Bu çevrimiçi alışveriş sitesini alışveriş davranışı bilgilerimi korur. & ,797 \\
\hline Bu çevrimiçi alışveriş sitesi kredi kartı bilgilerimi korur. &, 859 \\
\hline KMO & ,959 \\
\hline Açıklanan Toplam Varyans & 68,164 \\
\hline Cronbach's Alpha & ,975 \\
\hline \multicolumn{2}{|l|}{ Çevrimiçi Yeniden Satın Alma Niyeti } \\
\hline Yakın gelecekte kesinlikle bu çevrimiçi alışveriş sitesinden bir ürün satın alacağım. & ,803 \\
\hline Yakın gelecekte bu çevrimiçi alışveriş sitesinden bir ürün satın alma niyetim var. &, 837 \\
\hline Yakın gelecekte bu siteden bir ürün satın alabilirim. & ,891 \\
\hline Yakın gelecekte bu siteden bir ürün satın almayı umuyorum. & ,906 \\
\hline Yakın gelecekte bu siteyi tekrar ziyaret etmek isteyebilirim. &, 817 \\
\hline Yakın gelecekte bu siteyi tekrar ziyaret etmeye teşvik edilebilirim. &, 837 \\
\hline KMO & ,869 \\
\hline Açıklanan Toplam Varyans & 72,634 \\
\hline Cronbach's Alpha & ,920 \\
\hline
\end{tabular}

Tablo 2'de yer alan keşfedici faktör analizi sonuçlarına göre sporda çevrimiçi tüketim motivasyonu ekonomik, güvenlik-gizlilik, teslimat, ürün kalitesi, müşteri hizmetleri, kolaylık, bilgi, çeşitlilik ve sosyalleşme olmak üzere dokuz alt boyuttan oluşmaktadır. Sporda çevrimiçi tüketim motivasyonu değişkenin ifadeleri toplam varyansın \%68,65 açıklamakta olup ölçeğin güvenilirlik katsayısı \%93,6 olarak bulunmuştur.

Elektronik hizmet kalitesi ise etkinlik, sistem ulaşılabilirliği, gerçekleştirme ve gizlilik olmak üzere dört alt boyuttan oluşmaktadır. Elektronik hizmet kalitesi ölçeğinin toplam açıklanan varyansı \%68,16 ve güvenilirlik katsayısı \%97,5 olarak bulunmuştur.

Çevrimiçi yeniden satın alma niyeti ise tek boyut altında toplanmıştır. Çevrimiçi yeniden satın alma niyeti değişkeni toplam varyans $1 \% 72,63$ açıklamakta olup ölçeğin güvenilirlik katsayısı ise \%92 olarak bulunmuştur.

Araştırmanın $\mathrm{H}_{1}\left(\mathrm{H}_{1}\right.$ : Çevrimiçi tüketim motivasyonu yeniden satın alma niyeti üzerinde etkilidir) hipotezini test etmek için regresyon analizinden yararlanılmıştır.

Tablo 3: Sporda Çevrimiçi Tüketim Alt Boyutlarının Çevrimiçi Yeniden Satın Alma Niyeti Üzerindeki Etkisini Ölçen Regresyon Modelinin Özeti

\begin{tabular}{|c|c|l|l|l|l|l|}
\hline $\mathbf{R}$ & $\mathbf{R}^{2}$ & Düzeltilmiş $\mathbf{R}^{\mathbf{2}}$ & Tahmini Stn. Hata & $\mathbf{F}$ & Anlamlılık & Durbin-Watson \\
\hline, 715 &, 512 &, 499 &, 67139 & 41,662 &, $000^{*}$ & 2,0007 \\
\hline
\end{tabular}

Tablo 3 incelendiğinde sporda çevrimiçi tüketim alt boyutlarının çevrimiçi satın alma niyeti değişkenindeki değişimin \%49,9'unu açıkladığı bulgusuna ulaşılmıştır. Durbin-Watson katsayısı incelendiğinde ise modelde otokorelasyon olmadığ sonucuna ulaşılmıştır. 


\section{Tablo 4: Sporda Çevrimiçi Tüketim Motivasyonu Alt Boyutlarının Çevrimiçi Yeniden Satın Alma Niyeti Üzerindeki Etkisini Ölçen Regresyon Modeli Katsayıları}

\begin{tabular}{|c|c|c|c|c|c|}
\hline \multirow[t]{2}{*}{ Model } & \multicolumn{2}{|c|}{$\begin{array}{c}\text { Standardize Edilmemiş } \\
\text { Katsayılar }\end{array}$} & \multirow{2}{*}{$\begin{array}{c}\begin{array}{c}\text { Standart } \\
\text { Katsayılar }\end{array} \\
\text { Beta }\end{array}$} & \multirow[t]{2}{*}{$\mathbf{T}$} & \multirow[t]{2}{*}{ Anlamlılık } \\
\hline & B & Std. Hata & & & \\
\hline (Sabit) & ,519 &, 130 & & 3,990 & ,000 \\
\hline Ekonomik & ,292 & ,067 & ,408 & 4,832 & ,000 \\
\hline $\begin{array}{ll}\text { Güvenlik } & \text { ve } \\
\text { Gizlilik } & \\
\end{array}$ &,- 034 & ,038 &,- 036 &,- 892 & ,373 \\
\hline Teslimat &,- 086 &, 056 &,- 099 & $-1,544$ & , 123 \\
\hline Kalite &, 130 & ,070 & ,163 & 1,862 & ,063 \\
\hline $\begin{array}{l}\text { Müşteri } \\
\text { Hizmetleri }\end{array}$ &, 165 & ,061 & , 199 & 2,692 & ,063 \\
\hline Kolaylik &, 014 & ,061 & ,199 & 2,692 & ,007 \\
\hline Bilgi &,- 040 & ,066 &,- 041 &,- 608 &, 544 \\
\hline Çeşitlilik & ,206 &, 055 & ,207 & 3,756 & ,000 \\
\hline Sosyalleşme & ,087 & ,044 & ,106 & 1,976 & ,049 \\
\hline
\end{tabular}

Tablo 4 incelendiğinde ekonomik, kolaylık, çeşitlilik ve sosyalleşme alt boyutlarının çevrimiçi yeniden satın alma niyeti üzerinde anlamlı bir etkisinin olduğu; güvenlik-gizlilik, teslimat, kalite, müşteri hizmetleri ve bilgi boyutlarının çevrimiçi yeniden satın alma niyeti üzerinde anlamlı bir etkisi olmadığı sonucuna ulaşılmıştır. Elde edilen regresyon denklemi aşağıdaki gibidir.

$$
y=0,519+0,292(\text { ekonomik })+0,014(\text { kolaylık })+0,206(\text { çeşitlilik })+0,08(\text { sosyalleşme })
$$

$\mathrm{H}_{2}\left(\mathrm{H}_{2}\right.$ : Elektronik hizmet kalitesi çevrimiçi yeniden satın alma niyeti üzerinde etkilidir.) hipotezini test etmek için regresyon analizinden yararlanılmıştır. Aşağıdaki tabloda regresyon analizi sonuçları yer almaktadır.

Tablo 5: Elektronik Hizmet Kalitesi Alt Boyutlarının Çevrimiçi Yeniden Satın Alma Niyeti Üzerindeki Etkisini Ölçen Regresyon Modeli Özeti

\begin{tabular}{|c|c|l|l|c|l|l|}
\hline $\mathbf{R}$ & $\mathbf{R}^{2}$ & Düzeltilmiş R & Tahmini Stn. Hata & $\mathbf{F}$ & Anlamlılık & Durbin-Watson \\
\hline, 687 &, 472 &, 466 &, 69340 & 81,040 &, $000^{*}$ & 2,041 \\
\hline
\end{tabular}

Tablo 5 incelendiğinde elektronik hizmet kalitesi alt boyutlarının, çevrimiçi satın alma niyeti değişkenindeki değişimin \%46,6’sını açıkladığı görülmektedir. Bu oran kabul edilebilir bir açıklama oranıdır ve modelin anlamlı olduğunu göstermektedir. Modelde otokorelasyon olup olmadığının belirlenmesi için Durbin-Watson testinden yararlanılmıştır. Durbin Watson değerinin 1,5 ile 2,5 arasında olması otokorelasyon 

Perceptions on Repurchase Intention

olmadığı şeklinde yorumlanmaktadır (Kalaycı, 2010). Tablodaki ilgili sonuç incelendiğinde otokorelasyon olmadığı sonucuna ulaşılmıştır.

\section{Tablo 6: Elektronik Hizmet Kalitesi Alt Boyutlarının Çevrimiçi Yeniden Satın Alma Niyeti Üzerindeki Etkisini Ölçen Regresyon Modeli Katsayıları}

\begin{tabular}{|l|c|c|c|c|c|}
\hline \multirow{2}{*}{ Model } & \multicolumn{2}{|c|}{$\begin{array}{c}\text { Standardize Edilmemiş } \\
\text { Katsaylar }\end{array}$} & \multirow{2}{*}{$\begin{array}{c}\text { Standart } \\
\text { Katsayılar }\end{array}$} & \multirow{2}{*}{ T } & \multirow{2}{*}{ Anlamlılık } \\
\cline { 2 - 5 } & \multicolumn{2}{|c|}{ B } & Std. Hata & Beta & \\
\hline (Sabit) &, 890 &, 091 & & 9,732 &, 000 \\
\hline Etkinlik &, 325 &, 067 &, 408 & 4,832 &, 000 \\
\hline $\begin{array}{l}\text { Sistem } \\
\text { Ulaş1labilirliği }\end{array}$ &,- 087 &, 058 &,- 113 & $-1,500$ &, 135 \\
\hline Gerçekleştirme &, 011 &, 083 &, 013 &, 129 &, 898 \\
\hline Gizlilik &, 308 &, 056 &, 404 & 5,502 &, 000 \\
\hline
\end{tabular}

Tablo 6 incelendiğinde etkinlik ve gizlilik boyutlarının çevrimiçi yeniden satın alma niyeti üzerinde anlamlı bir etkisinin olduğu; sistem ulaşılabilirliği ve gerçekleştirme alt boyutlarının çevrimiçi yeniden satın alma niyeti üzerinde anlamlı bir etkisi olmadığı sonucuna ulaşılmıştır. Elde edilen regresyon denklemi aşağıdaki gibidir.

$$
y=0,890+0,325(\text { etkinlik })+0,308(\text { gizlilik })
$$

Anlamlı bulunmadığı için sistem ulaşılabilirliği ve gerçekleştirme boyutlarına ait katsayılara denklemde yer verilmemiştir. Etkilerin değerlendirilmesinde standardize değerler dikkate alınmıştır. Buna göre yeniden satın alma niyetini elektronik hizmet kalitesini etkinlik ve gizlilik boyutları etkilemektedir.

\section{Sonuç ve Öneriler}

Günümüzde spor pazarlaması faaliyetleri alanı içerisinde meydana gelen gelişmeler araştırmalara konu olmaktadır. Bu araştırmada tüketicilerin sporda çevrimiçi tüketim motivasyonlarının ve kulüplerin çevrimiçi ortamlarda sunmuş oldukları elektronik hizmet kalitesinin yeniden satın alma niyetine olan etkisi incelenmiştir.

Sporda çevrimiçi tüketim motivasyonunun alt boyutları olan ekonomik, kolaylık, çeşitlilik ve sosyalleşme çevrimiçi yeniden satın alma niyeti üzerinde etkilidir. Spor tüketicileri gerçekleştirmiş oldukları çevrimiçi satın alma süreçlerinde sunulan ürünlerin ve hizmetlerin ekonomik olmasına, ilgili satın alma işleminin ve internet sitesinin kolay kullanımına, ürün ve hizmet çeşitliliğine ve satın alma sonucunda oluşacak etkileşim sayesinde sosyalleşme eğilimlerine önem vermektedirler.

Sporda çevrimiçi tüketim motivasyonunu oluşturan alt boyutlarının çevrimiçi yeniden satın alma niyeti üzerindeki etkileri incelediğinde ekonomik alt boyutunun diğer alt boyutlara göre daha yüksek etkiye sahip olduğu gözlemlenmektedir. Tüketicilerin çevrimiçi ortamlarda spor ürünlerini satın almalarında ekonomik faktörler ve tasarruflar büyük önem taşımaktadır. Geleneksel mağazalar ile çevrimiçi mağazalar karşılaştırıldığında çevrimiçi ortamlardaki ürünlerin fiyatlarının mağazalarda yer alan 
ürünlere göre daha uygun olması bu durumu destekler niteliktedir. İnternetin tüketicilerin yaşamlarına girmesiyle birlikte ürün ve hizmetlerin fiyatlarını aşağıya doğru baskılayan bir ortam söz konusu olmuştur. Ayrıca bu durum son zamanlarda ülkemizde yaşanan ekonomik krizin yansımaları olarak değerlendirilebilir. Bu çıktıdan hareketle kulüplere fiyatlandırma politikalarını gözden geçirmeleri ve fiyat konusunda hassas bir tüketici grubuna yönelik çeşitli satış geliştirme ve fiyat indirimleri ile talebi canlandırma stratejileri uygulamaları önerilebilir.

Elektronik hizmet kalitesinin etkinlik ve gizlilik boyutlarının çevrimiçi yeniden satın alma niyeti üzerinde etkisi olduğu sonucuna da ulaşılmıştır. Kulüplerin çevrimiçi ortamlarda alışveriş aşamalarını tüketicinin isteklerine cevap verebilecek etkin bir şekilde düzenlemeleri ve tüketicilerin kişisel bilgilerinin korunması yeniden satın alma niyetini etkilemektedir. Bu durum tüketicilerin internet ortamında kişisel bilgilerin gizliliğine önem verdiklerini ortaya koymaktadır. Çevrimiçi ortamda alışveriş yapan tüketiciler elektronik ortamda paylaştıkları kişisel bilgilerin gizli kalmasını fazlasıyla önemsemektedir. Kulüpler tüketici verilerinin üçüncü kişilerden korunmasına ilişkin hassas davranmaları önerilmektedir. Ayrıca, kulüpler sahip olduğu internet altyapılarını geliştirerek alışveriş yapan taraftarların kişisel bilgilerini korumalı ve bu doğrultuda taraftarların güvenini sağlamalıdırlar. Bu durum tüketicilerin çevrimiçi satın alma davranışlarına olumlu yansıyarak, gerçekleştirmiş oldukları çevrimiçi alışveriş hacmini arttırabilir.

$\mathrm{Bu}$ çalışma spor pazarlaması çerçevesinde tüketicilerin çevrimiçi tüketim motivasyonlarının ve elektronik hizmet kalitesinin yeniden satın alma niyeti üzerindeki etkisini incelemektedir. Çalışma çevrimiçi ortamda mağazası olan ve en çok sayıda taraftara sahip dört büyük futbol kulüp taraftarını kapsamaktadır. Gelecekte yapılacak olan çalışmalarda sonuçların daha iyi yorumlanabilmesi için çevrimiçi ortamlarda mağazaları olan diğer kulüplerde araştırmaya dahil edilebilir. Bunun yanı sıra çalışma diğer spor branşlarında da gerçekleştirilebilir. Ayrıca, akıllı telefonların hayatımıza girmesiyle birlikte mobil uygulamalarından yapılan alışveriş oranları büyük bir artış göstermektedir. Gelecek çalışmalarda çevrimiçi ortamlar yerine mobil ortamlara ilişkin motivasyonlarının ve hizmet kalitesinin belirlenmesinin yarar sağlayacağ düşünülmektedir.

\section{Kaynakça}

Boshoff, C. (2007). A Psychometric Assessment of ES-Qual: A Scale to Measure Electronic Service Quality. Journal of Electronic Commerce Research, 8(1), 101-114.

Biscaia, R., Correia, A., Yoshida, M., Rosado, A., \& Marôco, J. (2013). The Role of Service Quality And Ticket Pricing on Satisfaction and Behavioural İntention within Professional Football. International Journal of Sports Marketing and Sponsorship, 14(4), 42-66. 

Perceptions on Repurchase Intention

Brown, M. T. (2003). An Analysis on Online Marketing in the Sport Industry: Users Activity, Communication Objectives and Perceived Benefits. Sport Marketing Quarterly 12(1), 48-55.

Carlson, J., \& O'Cass, A. (2010). Exploring the Relationships between e-Service Quality, Satisfaction, Attitudes and Behaviours in Content-driven e-Service Web Sites. Journal of Services Marketing.

Chang, H. H., Wang, Y.-H., \& Yang, W.-Y. (2009). The Impact of e-Service Quality, Customer Satisfaction and Loyalty on e-Marketing: Moderating Effect of Perceived Value. Total Quality Management \& Business Excellence, 20(4), 423-443.

Chang, T.-Z., \& Wildt, A. (1994). Price, Product Information and Purchase Intention: An Empirical Study. Journal Of The Academy Of Marketing Science 22(1), $16-27$.

Che, T., Peng, Z., Lim, K. H., \& Hua, Z. (2015). Antecedents of Consumers' Intention to Revisit an Online Group-buying Website: A transaction cost perspective. Information \& Management, 52(5), 588-598.

Chiu, W., \& Won, D. (2016). Relationship Between Sport Website Quality and Consumption Intentions: Application of a Bifactor Model. Psychological Reports, 118(1), 90-106.

Chiu, W., \& Won, D. (2016). Consumer-Brand Relationships in Sports Products and Repurchase Intention: An Application of the Investment Model. International Journal of Sports Marketing and Sponsorship, 17(3), 243-259.

Chou, S. W., \& Hsu, C. S. (2016). Understanding Online Repurchase Intention: Social Exchange Theory and Shopping Habit. Information Systems and e-Business Management, 14(1), 19-45.

Cox, J., \& Dale, B. G. (2001). Service Quality and e-Commerce: An Exploratory Analysis. Managing Service Quality: An International Journal.

Eunju, K., Kim, K., \& Zhang, H. (2008). A Cross Cultural Study of Antecedents of Purchase Intention for Sports Shoes in Korea and China. Journal of Global Academy Of Marketing Science, 157-177.

Evans, D. M., \& Smith , A. (2004). The Internet and Competitive Advantage: A Study of Australia's Four Premier Professional Sporting Leagues. Sport Management Review 7(1), 27-56. 
Tüketicilerin Spor Ürünlerine İlişskin Çevrimiçi Tüketim Motivasyonlarının ve Elektronik Hizmet Kalitesi Algılarının Yeniden Satın Alma Niyetleri Üzerindeki Etkilerinin İncelenmesi

Filo, K., Funk, D. C., \& Hornby, G. (2009). The Role of Web Site Content on Motive and Attitude Change for Sport Events. Journal of Sport Management, 23(1), 21-40.

Foroughi, B., Nikbin, D., Hyun, S. S., \& Iranmanesh, M. (2016). Impact of Core Product Quality on Sport Fans' Emotions And Behavioral Intentions. International Journal of Sports Marketing and Sponsorship, 17(2), 110-129.

Grönroos, C. (1984). A Service Quality Model and Its Marketing Implications. European Journal of Marketing 18(4), 36-44.

Grönroos, C. (2007). Service Management and Marketing: Customer Management in Service Competition. John Wiley \& Sons.

Ha, J. P., Kang, S. J., \& Kim, Y. (2017). Sport Fans in a "Smart Sport"(SS) Age: Drivers of Smartphone Use For Sport Consumption. International Journal of Sports Marketing and Sponsorship, 18(3), 281-297.

Haugh, B. R., \& Watkins, B. (2016). Tag Me, Tweet Me If You Want to Reach Me: An Investigation into How Sports Fans Use Social Media. International Journal of Sport Communication, 9(3), 278-293.

Hur, Y., Ko, Y., \& Claussen, C. (2012). Determinants of Using Sport Web Portals: An Empirical Examination of the Sport Website Acceptance Model . International Journal of Sports Marketing and Sponsorship 13(3), 6-25.

Hur, Y., Ko, Y., \& Valacich , J. (2007). Motivation and Concern for Online Consumption . Journal of Sport Management 21(4), 521-539.

James, J. D., \& Ross, S. (2004). Comparing Sport Consumer Motivations Across Multiple Sports. Sport Marketing Quarterly 13, 17-25.

Kalaycı, Ş. (2010). SPSS Uygulamalı Çok Değişkenli İstatistik Teknikleri (Vol. 5). Ankara, Turkey: Asil Yayın Dağıtım.

Kang, S. (2015). The Mobile Phone And Professional Sports: Fans' Use of Mobile Content For Loyalty, İdentification, And Fandom. International Journal of Sport Communication, 8(4), 452-476.

Kim, A. J., \& Ko , E. (2010). Impacts of Luxury Fashion Brand's Social Media Marketing On Customer Relationship And Purchase Intention. Journal Of Global Fashion Marketing 1(3), 164-171. 

Perceptions on Repurchase Intention

Ladhari, R. (2010). Developing e-Service Quality Scales: A Literature Review. Journal of Retailing and Consumer Services, 17(6), 464-477.

Lee, S. Y. (2017). Service Quality of Sports Centers and Customer Loyalty. Asia Pacific Journal of Marketing and Logistics, 29(4), 870-879.

Lee, G.-G., \& Lin, H.-F. (2005). Customer Perceptions of e-Service Quality in Online Shopping. International Journal of Retail \& Distribution Management 33(2), 161-176.

Oman, B., Pepur, M., \& Arnerić, J. (2016). The Impact of Service Quality and SportTeam Identification on the Repurchase Intention. Management: Journal of Contemporary Management Issues, 21(1), 19-46.

Jae Seo, W., Christine Green, B., Jae Ko, Y., Lee, S., \& Schenewark, J. (2007). The Effect of Web Cohesion, Web Commitment, and Attitude toward the Website on Intentions to Use NFL Teams' Websites. Sport Management Review, 10(3), 231-252.

Parasuraman, A., Zeithaml, V., \& Leonard, B. (1985). A Conceptual Model of Service Quality and its Implications for Future Research. The Journal of Marketing, 41-50.

Parasuraman, A., Zeithaml, V. A., \& Berry, L. L. (1988). SERVQUAL: A MultipleItem Scale for Measuring Consumer Perceptions of Service Quality. Journal of Retailing, 64(1), 12.

Parasuraman, A., Zeithaml, V. A., \& Malhotra, A. (2005). E-S-QUAL: A Multiple-item Scale for Assessing Electronic Service Quality. Journal of Service Research, 213-233.

Pavlou, P. A. (2003). Consumer Acceptance of Electronic Commerce: Integrating Trust and Risk with The Technology Acceptance Model. International Journal of Electronic Commerce 7(3), 101-134.

Rust, R., \& Lemon, K. (2001). E-Service and The Consumer. International Journal Of Electronic Commerce 5(3), 85-101.

Salisbury, W. D., Pearson, R., Pearson, A., \& Miller, D. (2001). Perceived Security and World Wide Web Purchase Intention. Industrial Management \& Data Systems 101(4), 165-176.

Santos, J. (2003). E-Service Quality: A Model of Virtual Service Quality Dimensions. Managing Service Quality 13(3), 233-246. 
Tüketicilerin Spor Ürünlerine İlişkin Çevrimiçi Tüketim Motivasyonlarının ve Elektronik Hizmet Kalitesi Algılarının Yeniden Satın Alma Niyetleri Üzerindeki Etkilerinin İncelenmesi

Seo, W. J., \& Green, B. C. (2008). Development of the Motivation Scale for Sport Online Consumption. Journal of Sport Management, 22(1), 82-109.

Smith, L. R., \& Smith, K. D. (2012). Identity in Twitter's Hashtag Culture: A SportMedia-Consumption Case Study. International Journal of Sport Communication, 5(4), 539-557.

Srivastava, K., \& Sharma, N. K. (2013). Service Quality, Corporate Brand Image, and Switching Behavior: The Mediating Role of Customer Satisfaction and Repurchase Intention. Services Marketing Quarterly, 34(4), 274-291.

Stephen, A. T. (2016). The Role of Digital and Social Media Marketing in Consumer Behavior. Current Opinion in Psychology, 10, 17-21.

Tang, T., \& Cooper, R. (2011). The First Online Olympics: The Interactions Between Internet Use and Sports Viewing. Journal of Sports Media, 6(1), 1-22.

Udo, G. J., Bagchi, K. K., \& Kirs, P. J. (2010). An Assessment of Customers' e-Service Quality Perception, Satisfaction and Intention. International Journal of Information Management, 30(6), 481-492.

Vale, L., \& Fernandes, T. (2018). Social Media and Sports: Driving Fan Engagement with Football Clubs on Facebook. Journal of Strategic Marketing, 26(1), 3755.

Wen, C., Prybutok, V. R., \& Xu, C. (2011). An Integrated Model For Customer Online Repurchase Intention. Journal of Computer Information Systems, 52(1), 14-23.

Witkemper, C., Lim, C. H., \& Waldburger, A. (2012). Social Media and Sports Marketing: Examining The Motivations and Constraints of Twitter Users. Sport Marketing Quarterly, 21(3).

Zeithaml, V. A. (2002). Service Excellence in Electronic Channels. Managing Service Quality 12(3), 135-139.

Zeithaml, V. A., Parasuraman, A., \& Malhotra, A. (2000). A Conceptual Framework for Understanding e-Service Quality: Implications for Future Research and Managerial Practice. Marketing Science Institute.

Zhou, T., Lu, Y., \& Wang, B. (2009). The Relative Importance of Website Design Quality and Service Quality in Determining Consumers' Online Repurchase Behavior. Information Systems Management, 26(4), 327-337. 